\title{
Foot Arch and Plantar Pressure in the Age of 17-21 Years
}

\author{
Arcus Pedis dan Tekanan Plantar pada Usia 17-21 Tahun
}

\author{
Arif Wicaksono $^{1 *}$, Sasanthy Kusumaningtyas ${ }^{2}$, Angela BM Tulaar ${ }^{3}$ \\ ${ }^{1}$ Department of Anatomy, Medical Faculty, Universitas Tanjungpura Pontianak \\ 2 Department of Anatomy, Medical Faculty, Universitas Indonesia Jakarta \\ ${ }^{3}$ Department of Physical Medicine and Rehabilitation, Cipto Mangunkusumo Hospital Jakarta
}

DATA OF ARTICLE:

Received: 08 Jan 2021

Reviewed: 14 June 2021

Revised: 05 July 2021

Accepted: 07 July 2021

*CORRESPONDENCE:

drarifwicaksono@gmail.com

DOI:

10.18196/mmjkk.v21i2.10799

TYPE OF ARTICLE:

Research

\begin{abstract}
Research on the plantar segment has not been widely carried out in Indonesia's population, even though the plantar segment data will be essential in further research and therapy of plantar-related problems. Therefore, this research intends to describe the plantar profile: the foot arch and the plantar pressure difference between the right and left foot. This research applied a cross-sectional study. Subjects were recruited from the Faculty of Medicine students, Universitas Indonesia, class 2012, with inclusion criteria aged 17-21 years and normal gait. Meanwhile, the exclusion criteria consisted of having postural abnormalities, a history of neuromusculoskeletal disorders in the lower limbs, a history of fractures in the spine and legs, a history of surgery on the spine and legs, and refusing to participate in the study. Research subjects stood on a plantar scanner, conducted at the Anatomy Laboratory, the Faculty of Medicine, Universitas Indonesia. The Mann-Whitney test was then used to analyze the difference in plantar pressure between the right and left foot. The results revealed that a hundred research subjects had a proportion of a low foot arch of $4 \%$, a normal foot arch of $89 \%$, and a high foot arch of $7 \%$. The median right plantar pressure was $273.5 \mathrm{KPa}$, while the median left plantar pressure was $253.5 \mathrm{KPa}$. The Mann-Whitney test showed a p-value of 0.954 for the pressure difference between right and left foot. There was no plantar pressure difference between the right and left foot.
\end{abstract}

Keywords: foot arch; plantar pressure; normal gait

Abstrak: Penelitian mengenai segmen plantar belum banyak dilakukan pada populasi di Indonesia. Data segmen plantar akan sangat penting dalam penelitian selanjutnya dan untuk terapi masalah yang berkaitan dengan plantar. Penelitian ini bertujuan untuk memperlihatkan profil plantar yaitu arcus pedis dan perbedaan tekanan plantar kanan dan kiri. Penelitian ini merupakan penelitian potong lintang. Subjek direkrut pada mahasiswa Fakultas Kedokteran Universitas Indonesia angkatan 2012 dengan kriteria inklusi berusia 17-21 tahun dan memiliki gaya berjalan normal. Kriteria eksklusi adalah memiliki kelainan postur, memiliki riwayat kelainan neuromuskuloskeletal pada tungkai bawah, riwayat fraktur pada tulang belakang dan tungkai, riwayat operasi pada tulang belakang dan tungkai, dan menolak untuk ikut dalam penelitian. Subjek penelitian berdiri pada alat pindai plantar, yang dilakukan di Laboratorium Anatomi Fakultas Kedokteran Universitas Indonesia. Uji Mann Whitney digunakan untuk analisis perbedaan tekanan plantar. Seratus subjek penelitian dengan hasil proporsi arcus rendah $4 \%$, arcus normal $89 \%$ dan arcus tinggi $7 \%$. Median tekanan plantar kanan adalah 273,5 KPa dan Median tekanan plantar kiri adalah 253,5 KPa. Uji Mann-Whitney menunjukkan p 0, 964. Proporsi arcus rendah $4 \%$, arcus normal $89 \%$ dan arcus tinggi $7 \%$. Tidak ada perbedaan tekanan yang bermakna pada kedua plantar.

Kata Kunci: lengkung kaki; tekanan plantar; gaya jalan normal 


\section{INTRODUCTION}

Data on the plantar segments of the population is vital as epidemiological support and can be used as a basis for further research or therapy if there are any abnormalities in the plantar segment. ${ }^{1}$ The data can also provide education, treatment, or rehabilitation for problems with pressure differences in the two feet..$^{2,3}$ Research on the plantar segment will show a low, normal, and high foot arch. ${ }^{4,5}$ In other countries, research on the plantar segment has found many characteristics in sports and has turned to the making of the plantar insoles. However, data in Indonesia is still low, people do not know their foot arch, and particular research tools are still limited.

In addition, the plantar segment has several characteristics, mainly foot arch and pressure. The pressure received by the two plantar is not the same. It will lead to problems, such as pain in the legs when standing and walking. ${ }^{6}$ The magnitude of the pressure difference also allows for pain and changes in gait.7 This difference can be treated or rehabilitated anatomically by reducing pressure on one foot or providing footwear with a particular shape. ${ }^{8} \mathrm{~A}$ study has shown that decreased pressure can provide comfort to the feet, reduce walking pain, and increase the duration and distance of running than before. ${ }^{9}$

Moreover, the foot can be checked and profiled. The profile obtains the foot arch and can assess foot pressure or surface area directly with the soil or ground. In this regard, advances in technology affect the type of tests that can be performed. Manual measurement with computer technology is now available. Several tests in anthropology profile measurements include os navicular height measurements, 3,10 longitudinal arch angle measurements, ${ }^{11}$ measurements using calipers, ${ }^{12}$ measurements using digital photography and radiographic, ${ }^{13}$ digital scanning and neutral suspension casting techniques, ${ }^{14}$ RGB-D cameras, ${ }^{15}$ flexible membrane pressure sensors, ${ }^{16}$ and $3 \mathrm{D}$ foot shapes. ${ }^{17}$

Compared with other methods, MatScan [Tekscan, US] has several advantages. MatScan is a noninvasive instrument that can provide data about the plantar, including the exact number (in this case, pressure in detail) compared with the plantar print that gives a little discomfort after testing caused by the ink or powder, and in plantar prints, one cannot get the pressure. However, other plantar systems are high cost and require very careful maintenance; yet, it is often used in studies exploring the walking mechanisms and the walking disorders.

In Hongkong, a study on the plantar profile was intended to consider insole or shoe factories to make more comfortable shoes, ${ }^{18}$ similar to a study in high school students in Bandung, Indonesia. ${ }^{19}$ In addition, research on Indonesian pilgrims showed that foot arch type was correlated to walking endurance. ${ }^{20}$ Nevertheless, there is still no research based on the population and use of plantar scanners in Indonesia. Therefore, the general objective of this study was to obtain a foot segment profile, with the specific objective of obtaining data on the foot arch and plantar pressure on the right and left foot.

\section{MATERIALS AND METHOD}

This research had passed ethical approval from the Health Research Ethics Committee of the Medical Faculty UI-RSCM number 256/H2.F1/ETIK/2013 on $29^{\text {th }}$ April 2013. This study is an analytical study at the Department of Anatomy, Faculty of Medicine, Universitas Indonesia. The research was conducted in AprilJune 2013.

Subjects were individuals at the end of bone fusion who met the inclusion and exclusion criteria. The inclusion criteria for this study were individuals aged 17-21 years and who had a normal gait. A normal gait has the following characteristics: walking in a straight line, walking in a still posture (no deviation), and no pain while walking. Subjects were asked to walk about six meters, which were then assessed for their gait.

Meanwhile, the exclusion criteria in this study consisted of having postural defects, such as lordosis, kyphosis, and scoliosis, a history of neuromusculoskeletal disorders in the limbs, a history of fractures in the lower back and/leg, a history of lower back surgery and/leg, and those who refused to participate in the study.

Then, the sample size was determined by the relative deviation of the estimated proportion using the following formula:

$$
n=\frac{z_{1-\alpha / 2}^{2}(1-P)}{\varepsilon^{2} P}
$$




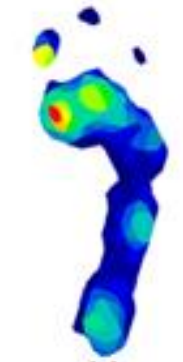

(a)

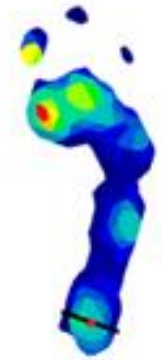

(b)

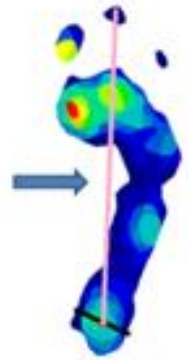

(c)

Figure 1. Foot Arch Measurement

The calculation result of the n-value was 98. In this study, subjects were chosen using the consecutive sampling method. Then, the authors rounded up the sample to 100 and decided to get the same number of male and female subjects.

The tools utilized in this research were weight scales and height measuring Health O Meter, plantar scanner MatScan, and demographic data questionnaire. The data obtained from the Matscan was a plantar image, which then the arch could be determined.

MatScan was used to show the appearance of the plantar arch and give a significant number of plantar pressures. The plantar arch can be divided into normal, low, and high according to this way. First, the plantar pressure image was saved as (a) in figure 1 (a), then a center point was made on the heel (fig. 1 (b)), and a foot axis line was drawn between the center point of the heel and the second metatarsal (fig.1 (c)). Normal arch is when the median segment of the foot is contiguous to the foot axis line. The low arch is when the median segment of the foot crosses the foot axis line, or all median parts of the median segment touch the ground. Meanwhile, the high arch is when the median segment of the foot is far from the foot axis line, or there is no median part of the median segment that touches the ground.

Figure 2 shows the appearance of the foot arch based on MatScan after the foot line was added. Besides, the other data were the pressures. The pressure differences between the right and left foot were analyzed utilizing the Mann-Whitney test.

Moreover, in the early examination, subjects were interviewed about demographic data and pain or discomfort while standing and walking.

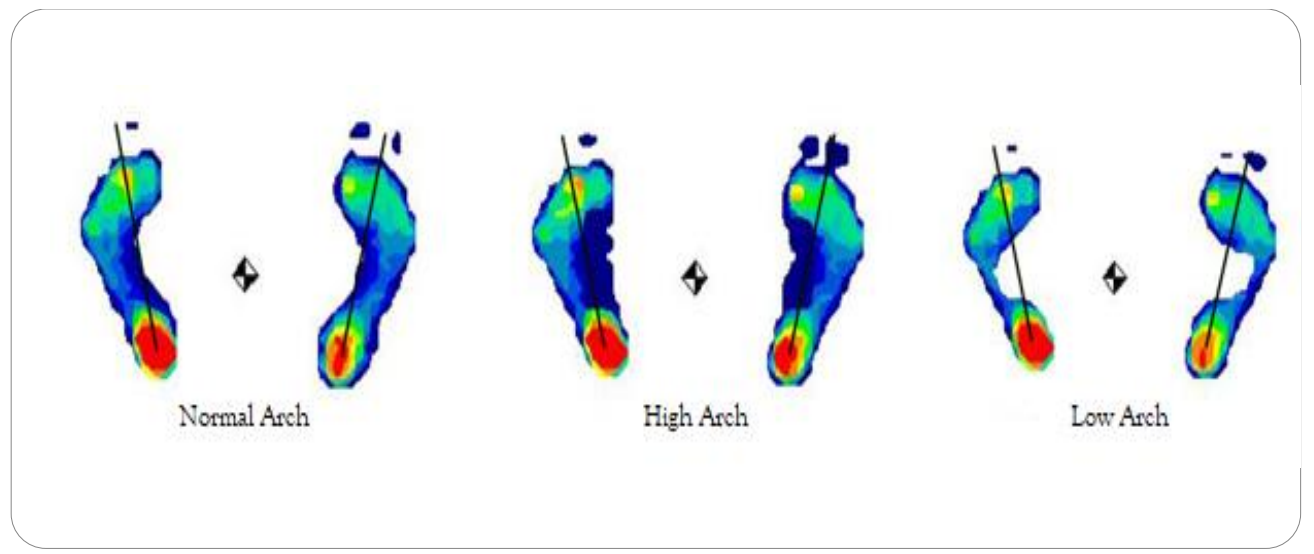

Figure 2. Foot Arch based on MatScan

\section{RESULTS}

The study subjects' characteristics are as follows: 50 (50\%) subjects were male, and 50 (50\%) subjects were female. The age, height, weight, and Body Mass Index (BMI) were normally distributed, as presented in Table 1. 
Table 1. Characteristics of the Subjects

\begin{tabular}{ccccc}
\hline & No. Characteristic & Mean & SD & \multicolumn{1}{c}{ Range } \\
\hline 1. & Age (years) & 18.88 & 0.83 & $17-21$ \\
2. & Height $(\mathrm{cm})$ & 162.83 & 8.88 & $142-182$ \\
3. & Weight $(\mathrm{kg})$ & 60.59 & 11.55 & $38.20-98$ \\
4. & BMI $\left(\mathrm{kg} / \mathrm{m}^{2}\right)$ & 22.79 & 3.56 & $17.07-24$ \\
\hline
\end{tabular}

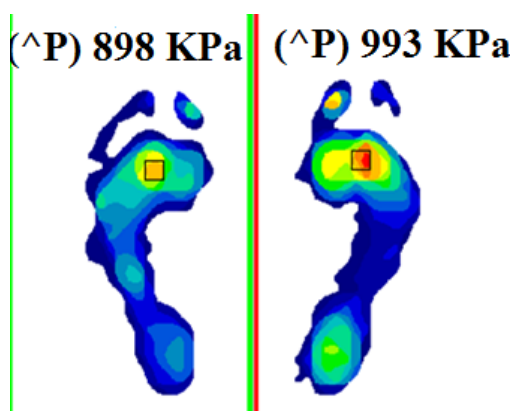

Figure 3. MatScan Result on Plantar Pressure

For the plantar research subjects' characteristics, a total of 89 subjects ( $89 \%)$ had a normal foot arch, seven subjects ( $7 \%$ ) had a high foot arch, and four subjects (4\%) had a low foot arch. Normally, the foot arch was the same in the right and left foot, as proven in this study.

The median right plantar pressure was $273.5 \mathrm{kPa}$ and $314 \mathrm{kPa}$ in mode. The median left plantar pressure was $253.5 \mathrm{kPa}$ and $310 \mathrm{kPa}$ in mode. The median difference between right and left plantar pressure was 27 $\mathrm{kPa}$ to $18 \mathrm{kPa}$ and $27 \mathrm{kPa}$ in mode. The appearance of pressure (colors) and the value $(\mathrm{KPa})$ can be seen in Figure 3 .

In addition, a total of 56 subjects (56\%) had a higher mean on the right plantar pressure, and 44 subjects (44\%) had a higher mean on the plantar left. The median point of the highest right plantar pressure was 513 $\mathrm{kPa}$ with modes 445 and $642 \mathrm{kPa}$. Besides, the Mann-Whitney test showed $\mathrm{p}=0.954$; statistically, there was no difference between right and left plantar pressure.

\section{DISCUSSION}

The subjects in this study had undergone the end of bone fusion, known as the bones of the foot's arch. In this research, if there were no external injury to the foot, the foot arch would barely remain as its nature. The subject's age group can minimize the bias from the foot arch changes based on the bone growth process. In this regard, a history of absence in several deformities or injuries strengthens the foot arch form.

A person's foot arch can be classified into a normal foot arch, a high arch (pes cavus), and a low arch (pes planus). A person with normal arches has no complaints. In high arches, the midfoot region is not in contact with the surface, and there is no or minimal inversion or eversion when standing. This type of arch has poor pressure absorption. Meanwhile, the low arch type is the opposite of the high arch type. This type of arch tends to move excessively, where most of the plantar surface touches the surface and weakens the medial side. This type of arch causes excessive pronation, especially during the support phase of walking. ${ }^{21}$

Moreover, foot abnormalities can occur due to many causes, such as congenital bone malformations, muscle paralysis or spasticity, chronic stress and strain, improper shoes, or a combination of these. Abnormalities can also be congenital and acquired disorders. ${ }^{22}$

This study obtained foot arch prevalence: normal foot arch of $89 \%$, high arch of $7 \%$, low foot arch of $4 \%$ in 100 study subjects, with the age range of 17-21 years utilizing a MatScan. No study has specifically discussed the plantar profile in Indonesia with MatScan. In Australia, a study showed foot arch prevalence: normal foot arch of $38 \%$, low arch of $33.7 \%$, and high arch of $28.3 \%$ in 92 study subjects, with the age range of 18-45 years. ${ }^{4}$ In America, a study resulted: normal foot arch of $44.3 \%$, low arch of 36.1\%, and high arch of 19.6 $\%$ in 61 study subjects, with the age range of $18-77$ years. ${ }^{6}$

There are several similar findings in this study. First, the subject's age group started in 17 to 18 years old, adult population at the end of bone fusion. Second, the number of subjects in each study was 100 or below (range 61 to 100 subjects). Third, most foot arches were normal foot arch. 
Some foot arch studies in children definitely intended to research the changing form of foot arch during their growth period, including bones and muscular growth, activities, and insole use. At the age of 17, there will be no more changes in bone and muscular to affect the foot arch's form.

Furthermore, the number of subjects depends on the researcher's goals, the method, the instrument, and the research place. Different places, regions, cities, or even countries might offer different research subject's characteristics. The use of instruments can also give different perspectives and experiences both for the researcher and the subjects.

All studies uncovered that most of the subjects had normal foot arch. Subjects with normal foot arch usually had no problem and no complaint regarding their foot. Besides, this study is an initial study of foot arch that can be developed further to seek the relationship between foot arch and gender, foot arch and the foot problems, foot arch and body mass index, and foot arch and plantar pressure. Study to the different populations can add foot arch database in Indonesia and the world, making people start thinking about their body's health from the foot.

In this study, plantar pressure examined normal subjects without any interruption or neuromusculoskeletal posture. The mean of right plantar pressure was $313.83 \mathrm{kPa}$, the highest mean of right plantar pressure reached $1344 \mathrm{kPa}$, and the lowest range was $52 \mathrm{kPa}$ to $1293 \mathrm{kPa}$. The mean of left plantar pressure was $307.18 \mathrm{kPa}$, the highest mean of left plantar pressure reached $1182 \mathrm{kPa}$, and the lowest range was $48 \mathrm{kPa}-1134 \mathrm{kPa}$. Thus, there was a big difference in right and left plantar pressure with a mean of $14.6 \%$ and a range of $0.01-14.86 \%$. This difference should be resulted in pain or discomfort feeling while standing and walking. However, from the interview, later after examination, none of the subjects felt pain or discomfort.

Earlier, research was conducted in 2012 by Sanghan et al. in one of the hospitals in Sangkhla, Thailand, in patients suffering from stroke and those who did not suffer a stroke as a control. Thirty subjects aged 40-55 years consisted of 24 control subjects, and eight subjects studied stroke patients using a Pedar-X insole plantar pressure system. It showed a difference of 4.28 to $4.59 \%$ in the control group and 25.06 to $29.85 \%$ in the stroke patients. It indicated that stroke could reduce plantar pressure on the plantar side of the pain by $20-25 \%$ of the normal plantar pressure difference. ${ }^{7}$

However, there is no specific research exploring plantar pressure in normal populations or the child or elderly population; therefore, the current authors could only compare the data with the pathological disease. Statistically, there was no plantar pressure difference between the right and left foot. Plantar pressure was likely more explored in populations with handicaps or diseases. How about in a normal population? Research can be conducted in normal populations to search plantar pressure and its relations with daily activities, physical activities, problems when standing, walking, running, and using shoes in their daily lives.

This study's limitation was that it was only conducted in the age of 17-21 years, so that it could not describe childhood, adult, and older population. This research was also conducted on a normal population; then, it could not be compared with a person with a handicap or disease.

\section{CONCLUSION}

In conclusion, this research obtained the prevalence of a normal arch of $89 \%$, followed by a high arch of $7 \%$ and a low arch of $4 \%$. Besides, there was no difference between right and left plantar pressure.

\section{CONFLICT OF INTEREST}

There are no conflicts of interest in this research.

\section{REFERENCES}

1. Menz HB, Dufour AB, Riskowski JL, Hillstrom HJ, Hannan MT. Foot Posture, Foot Function and Low Back Pain: The Framingham Foot Study. Rheumatol (United Kingdom). 2013; 52(12): 2275-82. https://doi.org/10.1093/rheumatology/ket298

2. Rogati G, Leardini A, Ortolani M, Caravaggi P. Validation of a Novel Kinect-based Device for 3D Scanning of the Foot Plantar Surface in Weight-bearing. J Foot Ankle Res. 2019; 12(1): 1-8. https://doi.org/10.1186/s13047-019-0357-7 
3. Nilsson MK, Friis R, Michaelsen MS, Jakobsen PA, Nielsen RO. Classification of the Height and Flexibility of the Medial Longitudinal Arch of the Foot. J Foot Ankle Res [Internet]. 2012; 5(1): 3. 1 https://doi.org/10.1186/1757. $\underline{1146-5-3}$

4. Buldt AK, Forghany S, Landorf KB, Murley GS, Levinger P, Menz HB. Centre of Pressure Characteristics in Normal, Planus and Cavus Feet. J Foot Ankle Res. 2018; 11(1): 1-9. https://doi.org/10.1186/s13047-018-0245. $\underline{6}$

5. Wong CK, Weil R, de Boer E. Standardizing Foot-type Classification Using Arch Index Values. Physiother Canada. 2012; 64(3): 280-3. https://doi.org/10.3138/ptc.2011-40

6. Hillstrom HJ, Song J, Kraszewski AP, Hafer JF, Mootanah R, Dufour A, et al. Foot Type Biomechanics Part 1: Structure and Function of the Asymptomatic Foot. Gait Posture. 2013; 37(5): 445-51. https://doi.org/10.1016/j.gaitpost.2012.09.007

7. Sanghan S, Chatpun S, Leelasamran W. Plantar Pressure Difference: Decision Criteria of Motor Relearning Feedback Insole for Hemiplegic Patients. $4^{\text {th }}$ International Conference on Bioinformatics and Biomedical Technology. Singapore: IACSIT Press; 2012. 29-33.

8. McKeon PO, Hertel J, Bramble D, Davis I. The Foot Core System: A New Paradigm for Understanding Intrinsic Foot Muscle Function. Br J Sports Med. 2015; 49(5): 290. https://doi.org/10.1136/bjsports-2013. $\underline{092690}$

9. Wu SC, Jensen JL, Weber AK, Robinson DE, Armstrong DG. Use of Pressure off Loading Devices in Diabetic Foot Ulcers. Do We Practice What We Preach? Diabetes Care. 2008; 31(11): 2118-9. https://doi.org/10.2337/dc08-0771

10. Roth S, Roth A, Jotanovic Z, Madarevic T. Navicular Index for Differentiation of Flat Foot from Normal Foot. Int Orthop. 2013; 37(6): 1107-12. https://doi.org/10.1007/s00264-013-1885-6

11. Roy H, Bhattacharya K, Deb S, Ray K. Arch Index: An Easier Approach for Arch Height (A Regression Analysis). Al Ameen J Med Sci. 2012; 5(2): 10.

12. Pohl MB, Farr L. A Comparison of Foot Arch Measurement Reliability Using Both Digital Photography and Calliper Methods. J Foot Ankle Res. 2010; 3(1): 1-6. https://doi.org/10.1186/1757-1146-3-14

13. Cobb SC, James CR, Hjertstedt M, Kruk J. A Digital Photographic Measurement Method for Quantifying Foot Posture: Validity, Reliability, and Descriptive Data. J Athl Train. 2011; 46(1): 20-30. https://doi.org/10.4085/1062-6050-46.1.20

14. Carroll M, Annabell ME, Rome K. Reliability of Capturing Foot Parameters Using Digital Scanning and the Neutral Suspension Casting Technique. J Foot Ankle Res [Internet]. 2011; 4(1): 9. https://doi.org/10.1186/1757-1146-4. $\underline{9}$

15. Chun S, Kong S, Mun KR, Kim J. A Foot-arch Parameter Measurement System Using a Rgb-D Camera. Sensors (Switzerland). 2017;17(8). https://doi.org/10.3390/s17081796

16. Zheng T, Yu Z, Wang J, Lu G. A New Automatic Foot Arch Index Measurement Method Based on a Flexible Membrane Pressure Sensor. Sensors (Switzerland). 2020; 20(10). https://doi.org/10.3390/s20102892

17. Stanković K, Booth BG, Danckaers F, Burg F, Vermaelen P, Duerinck S, et al. Three-dimensional Quantitative Analysis of Healthy Foot Shape: a Proof of Concept Study. J Foot Ankle Res. 2018; 11(1): 1-13. https://doi.org/10.1186/s13047-018-0251-8

18. Xiong S, Goonetilleke R, Witana C, Lee Au E. Modelling Foot Height and Foot Shape-related Dimensions. Ergonomics. 2008; 51(8): 1272-89. https://doi.org/10.1080/00140130801996147

19. Abdurrahman IR, Tahid A, Fathurachman. Foot Anthropometric Profile of High School Students in Bandung. Althea Med J. 2018; 5(2): 93-7. https://doi.org/10.15850/amj.v5n2.1418

20. Lutfie SH. Hubungan antara Derajat Lengkung Kaki dengan Tingkat Kemampuan Endurans pada Calon Jemaah Haji. Cermin Dunia Kedokteran. 2010; 178: 343-6.

21. Hamill J, Knutzen KM, Derrick TR. Biomechanical Basis of Human Movement. $4^{\text {th }}$ ed. Lippincott Wiliams \& Wilkins. Philadelphia: Wolters Kluwer; 2013. 506.

22. Houglum PA, Bertoti DB. Brunnstrom's Clinical Kinesiology. $6^{\text {th }}$ ed. Brunnstrom's Clinical Kinesiology. Philadelphia: F.A. Davis Company; 2012. 745. 